\section{ECCOMAS}

Proceedia
COMPDYN 2021

$8^{\text {th }}$ ECCOMAS Thematic Conference on Computational Methods in Structural Dynamics and Earthquake Engineering

M. Papadrakakis, M. Fragiadakis (eds.)

\title{
NUMERICAL MODELLING OF MASONRY INFILL WALLS IN EXISTING STEEL FRAMES
}

\author{
Luigi Di Sarno ${ }^{1 *}$, Jing-Ren Wu ${ }^{1}$, Fabio Freddi ${ }^{2}$, Mario D’Aniello ${ }^{3}$, Stathis Bousias ${ }^{4}$, Fer- \\ nando Gutiérrez-Urzúa ${ }^{2}$, Raffaele Landolfo ${ }^{3}$ and Nikolaos Stathas ${ }^{4}$ \\ ${ }^{1}$ Department of Civil Engineering and Industrial Design, University of Liverpool \\ The Quadrangle, Brownlow Hill, Liverpool, L69 3GH, UK \\ e-mail: \{luigi.di-sarno,jingren.wu\}@liverpool.ac.uk
}

${ }^{2}$ Department of Civil, Environmental and Geomatic Engineering, University College London

Gower Street, London, WC1E 6BT, UK

\{f.freddi,f.urzua\}@ucl.ac.uk

3 3Department of Structures for Engineering and Architecture, University of Naples Federico II

Corso Umberto I, 40, 80138 Napoli NA, Italy

\{mdaniel,raffaele.landolfo\}@unina.it

${ }^{4}$ Structures Laboratory, Department of Civil Engineering, University of Patras

26504 Patras, Greece

\{sbousias,stathas\}@upatras.gr

\begin{abstract}
It is now widely recognised that masonry infill plays an essential role in the seismic behaviour of existing steel buildings; however, there is still a lack of clear guidance on the modelling of masonry infill in the current Eurocode 8-Part 3. Several methods for the numerical modelling of masonry infills have been proposed in literature over the past few decades, which either adopt a detailed approach (micro-model) or a simplified approach (macromodel). In the former case, bricks are individually modelled, taking into account the brickmortar cohesive interface, which is able to provide detailed insights of the behaviour of masonry infills and the frame-wall interaction but usually at a high computational cost. On the other hand, a simplified model can be easily built within finite element software, most of which replace the infill wall panel with one or more equivalent struts in the diagonal direction. It has been demonstrated that the strut models can simulate RC infilled structures' global response with acceptable accuracy; however, there are still no adequate recommendations for their modelling within steel frames. Besides, these models are generally incapable of capturing the interactions between the infills and the frame members. To this end, the present paper numerically investigates an Abaqus macro-model of the infilled steel frame, which was experimentally tested as part of the recent SERA HITFRAMES project. The preliminary re-
\end{abstract}


sults shows that the different detailing of steel frames could lead to different damage patterns in the infill walls when compared to $R C$ frames. In particular, instead of a single diagonal strut, at most three struts were observed in this study. The results also suggested that the number and geometry of struts could change with increasing displacement demands, hence it might not be appropriate to use the same strut model for infill walls on different floors.

Keywords: Seismic Behaviour, Masonry Infill, Existing Steel Frame, Experimental Test 


\section{INTRODUCTION}

Masonry infill walls were widely used in existing steel frame structures as exterior walls mainly for insulation and aesthetic purposes; hence in the code-based assessment procedures of existing buildings, e.g., Eurocode 8-Part 3 [1], they are typically considered as nonstructural components. As a consequence, only the self-weight of infill walls is usually considered during the assessment, while their effects on the structural behaviour under lateral load are often neglected. However, it has been widely recognised that masonry infill can significantly affect the seismic response of structures, as they considerably influence the lateral stiffness and strength of structures (and their distribution), as well as the energy dissipation capacity under seismic loading [2-8]. In addition, the strut action of infill wall panels may also exert concentrated force to beams, columns and beam-column joints, increasing local seismic demands. Besides, in the case of infill walls not uniformly distributed, e.g., non-infilled ground floor, severe soft-storey mechanisms can also be triggered [9-11], leading to complete failure of the non-infilled storey.

Currently, a considerable number of studies focused on the behaviour of masonry infills within reinforced concrete (RC) frames, while the current knowledge level on the behaviour of infilled steel frames is still inadequate. Although the masonry infill confined by RC and steel frames share some commons in their seismic response, the different characteristics of steel frames may significantly alter masonry infill response. Steel frames are usually more flexible and more ductile and have different features and detailing compared to RC members, such as the aspect ratio of the frames and the geometries of steel beams and columns. Moreover, when involved in the infill-frame interactions, some local details typical of steel structures, e.g., stiffener plates and connections, may cause local stress concentration in the wall and, consequently, lead to a different response and failure mode of the masonry infills. Despite some experimental tests investigated the behaviour of infilled steel frame over the past few decades [e.g., 6, 12, 13], and a few simplified models have been proposed [e.g., 14, 15], further research is still of great necessity for the development of simplified models that can be used in practice for the assessment of infilled steel buildings. In addition, within the European context, there is an urgent need for additional and detailed rules and recommendations for the assessment of existing steel structures [e.g., 16] to be implemented within an updated version of the Eurocode 8-Part 3. These should include and consider the interaction with the masonry infills, thus promoting reliable assessment procedures.

Finite element modelling of masonry infill can be classified into two groups, namely $\mathrm{mi}$ cro- and macro-modelling. Detailed micro-modelling approaches usually include a detailed description of brick units and mortar as continuum elements and the brick-mortar interfaces to simulate the cohesive behaviour between brick units and mortar. Such models are able to reproduce the basic mechanisms of the masonry unit, hence are more likely to capture the complex damage patterns of masonry infill accurately. However, the high computational cost of detailed micro-models usually constrains their application to small structures. To this end, simplified micro-models were proposed as an alternative to detailed micro-models, which usually neglect the geometry of mortar and utilise expanded brick units to account for the thickness of mortar [17-19]. Subsequently, the material properties are often defined based on masonry samples, and the interactions between expanded brick units are simulated through cohesive elements or surface-based cohesive behaviour. The simplified micro-modelling can effectively reduce the computational cost but may lead to less accurate results. On the other hand, macro-modelling approaches consider the masonry infill as homogeneous isotropic material, whose mechanical properties can be defined based on various material tests of masonry triplets $[11,20,21]$. As a cost-effective computational strategy, macro-models are usually 
adopted while investigating the global response of infilled frames and/or to perform preliminary analyses of the stress distribution in the infill wall panel.

The present paper investigates the behaviour of infilled steel moment frames through the macro-modelling approach. The finite element models are validated based on the results of large-scale experimental tests conducted on a one-bay two-storey infilled steel frame as part of the HITFRAMES SERA project. The steel frame was designed to be representative of typical existing steel frames with inadequate sesimic detailing at joints. A pushover analysis is carried out, providing insights into the response of masonry infills. In particular, the change of number and geometry of struts formed in the infill walls were investigated considering increasing displacement demands.

\section{EXPERIMENTAL TEST}

\subsection{Description of the steel frame}

A two-storey single-bay 3:4 scaled steel frame was experimentally tested to investigate the behaviour of masonry infill confined by steel members. The test frame had a storey height of $2.5 \mathrm{~m}$, and span of 3.5 and $6.5 \mathrm{~m}$ in the transverse $(\mathrm{X})$ and longitudinal $(\mathrm{Y})$ direction, respectively. A sketch of the steel frame is shown in Figure 1. The columns, primary and secondary beams profiles were HE 180A, IPE 200 and IPE 140, respectively. The test was performed in the X-direction with the columns placed along with their weak axis; beam-to-column joints were made through full penetration welds with stiffeners installed to increase joints' rigidity, while beam-to-beam connections, for the primary beams, were placed at a distance of $400 \mathrm{~mm}$ with respect to the column axis. Besides, the columns' bases were welded to $30 \mathrm{~mm}$-thick steel plates with stiffeners to ensure their rigidity. The stiffened beam-column joints, the beam-to-beam connection and column bases are shown in Figure 2.
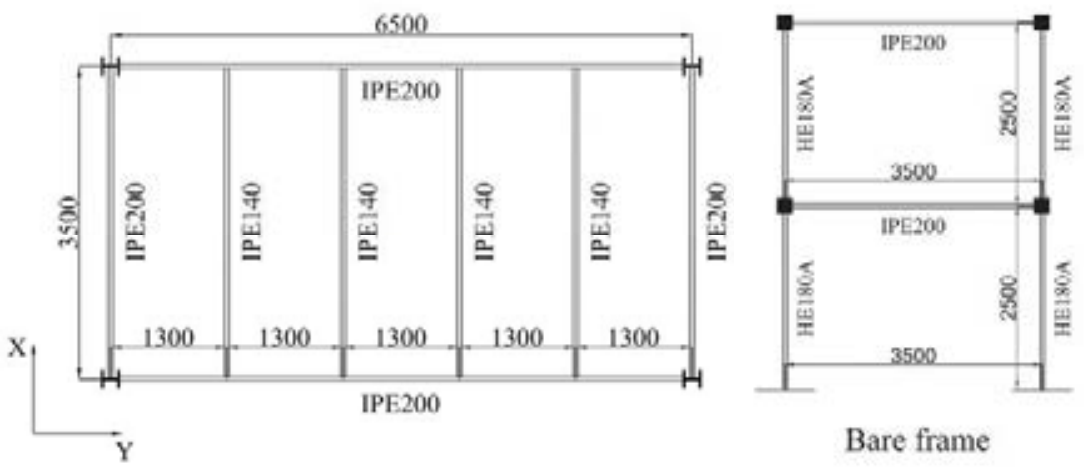

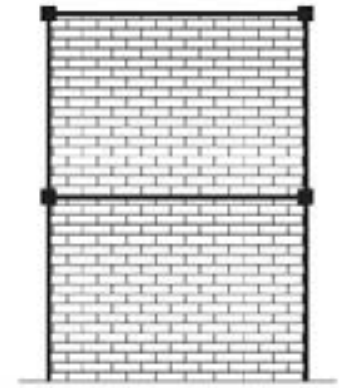

Infilled frame

Figure 1: Plan and side view of the steel frame experimentally tested in the laboratory.
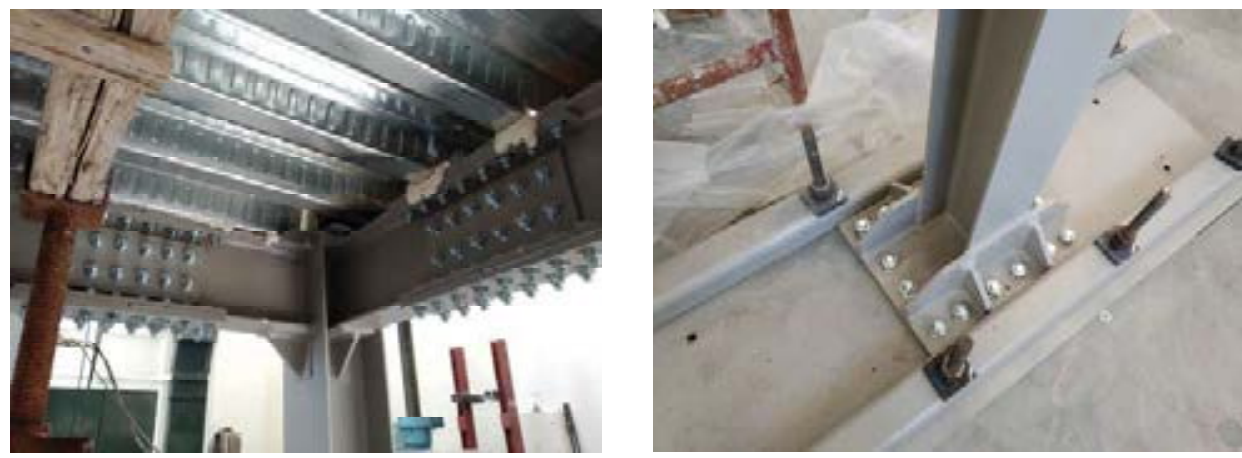

Figure 2: Detailing at the beam-column joints (left) and column base (right) of the test frame. 
The test frame included a composite slab at both storeys, consisting of $150 \mathrm{~mm}$-thick concrete slabs poured on a $1.25 \mathrm{~mm}$-thick corrugated steel sheet. Shear studs were implemented on both external and internal beams to ensure the transfer of applied horizontal loads to the steel frame through the slab. However, shear studs were omitted in the 0.5 -m-wide regions around the columns to avoid the development of composite actions in the joints. Finally, only the masonry infill in the transverse direction of the steel frame were included in the experimental test, each consisting of two layers of $58 \mathrm{~mm}$-thick perforated bricks of size $58 \times 83 \times$ $190 \mathrm{~mm}$.

\subsection{Experimental setup}

The test frame is shown in Figure 3 and was built in the laboratory, according to standard European constructional practice. The steel members were prepared in the workshop and fully assembled in the lab. Two parallel tubular beams were placed on top of each steel base plates and anchored to the strong floor in order to increase the rigidity of the base restraints of the test frame. Besides, the composite slab was built following the assembly of the bare steel frame, where the corrugated steel sheets were installed on the beams and fixed with the shear connectors, with the concrete slab subsequently cast and poured on-site.
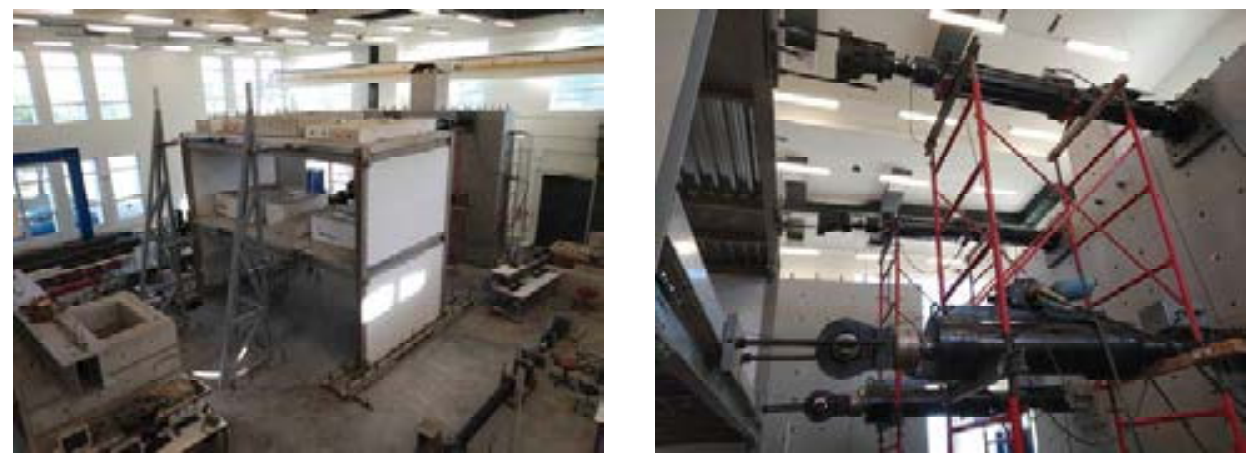

Figure 3: Experimental setup and positions of the actuators.

As shown in Figure 3, two actuators were placed at each storey of the test frame and connected to the reaction wall. Additionally, pre-cast concrete blocks were placed on the slab of each storey to simulate the gravity loads imposed on the structure, which would influence beams and columns' behaviour. It is noteworthy that additional concrete blocks were used to represent the mass of infill walls in the preliminary dynamic characterisation tests and were successively removed upon the installation of infill walls.

\subsection{Experimental test scheme}

A snap-back test was performed to capture the frame's modal properties for both the bare and infilled configurations. The initial displacement imposed on the frame also allowed the definition of the test frame's lateral stiffness. Both stiffness and modal properties were used for the numerical models' calibration.

After the modal characterisation test, pseudo-dynamic (PsD) displacements' control tests were performed to investigate the infilled frame's behaviour subjected to an earthquake sequence. Three ground motions, recorded during the 2016 Central Italy earthquakes, were selected to define the earthquake sequence used in the PsD tests. The time-history of accelerations of the earthquake sequence is shown in Figure 4. Two scaling factors (SF) of the earthquake sequence, $\mathrm{SF}=1.0$ and 3.0, were used during the PsD tests. The scaling factors were decided based on comparisons of the response spectra of selected ground motions with 
the code-based elastic response spectrum, where the use of unit scaling factor was to investigate the behaviour of the test frame subjected to real earthquakes, while the scaling factor of 3.0 was adopted to ensure the failure of the test frame, i.e., the collapse of infill walls and severe yielding of steel members.

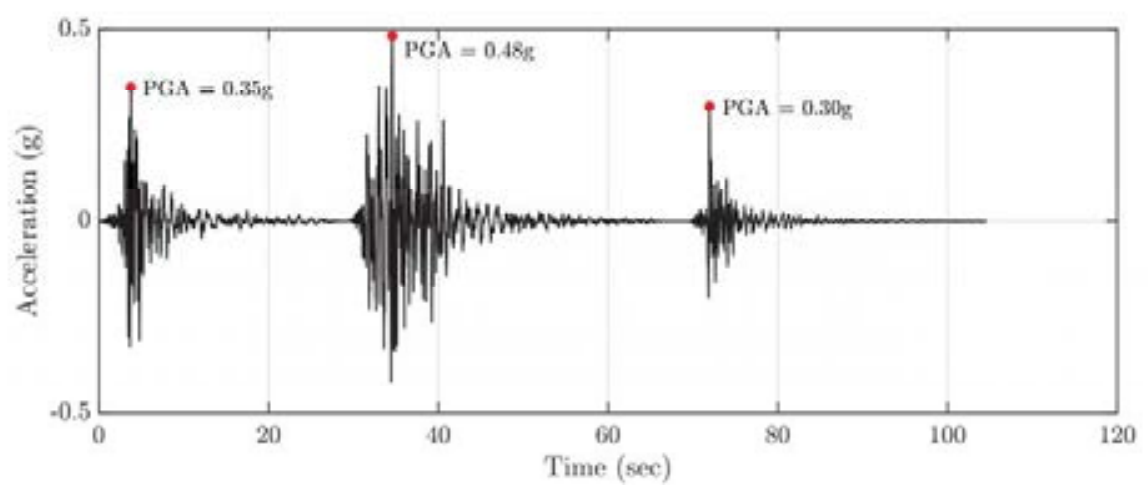

Figure 4: Accelerogram of the selected earthquake sequence.

\subsection{Experimental results}

The response of the infilled steel frame recorded during the entire PsD test, i.e., top storey displacement against base shear, is shown in Figure 5(a). Aside from the response curve, envelopes are also presented individually for the positive and negative direction. Subsequently, the corresponding backbone curve could also be derived based on the envelopes, which was assumed to be symmetric in the positive and negative direction.

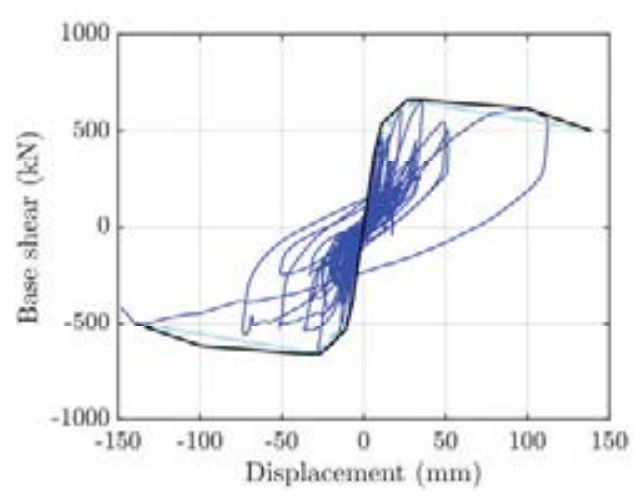

(a)

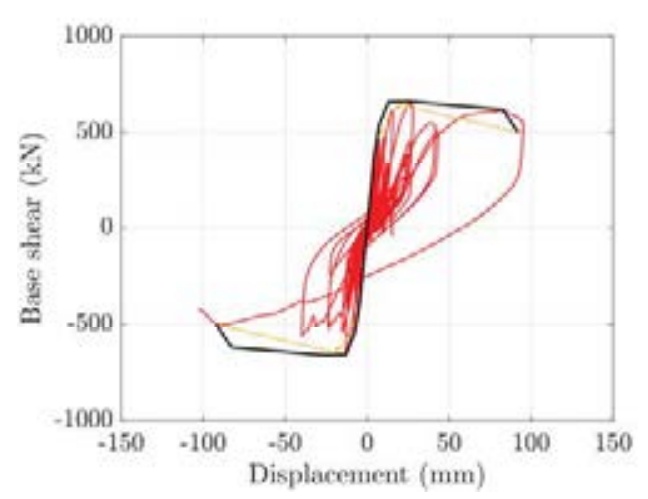

(b)

Figure 5: Response of the infilled steel frame with backbone curves: a) global response; b) first storey displacement against base shear.

As shown in Figure 5(a), the first significant change of the frame's lateral stiffness corresponds to a $10 \mathrm{~mm}$ top storey displacement. Then the steel frame reached the maximum base shear of around $650 \mathrm{kN}$ when the lateral displacement at the top storey was approximately 25 $\mathrm{mm}$. This also marked the onset of negative stiffness in the backbone curve of the steel frame. In addition, degradation of strength was also noticed at $100 \mathrm{~mm}$ of top floor displacement, where the capacity of base shear dropped by about $8 \%$ to $600 \mathrm{kN}$. Lastly, the largest top storey displacement experienced during the PsD test corresponds to $140 \mathrm{~mm}$, when the collapse of infill occurred, and the test was terminated.

The pushover numerical analysis requires the knowledge of the forces and displacements' distribution at both storeys. To this end, the response history at the first storey was determined and is shown in Figure 5(b). This also included the envelopes for the definition of the corre- 
sponding backbone curve. The comparison of the backbone curves for both storeys is shown in Figure 6, and six points were selected for the determination of displacement ratios of the top storey to the first storey, as also summarised in Table 1. It can be concluded that initially the displacement ratio was around 1.5, however, when the displacements were increased, the ratio was slightly reduced to 1.34 at point $\mathrm{D}$ and 1.20 at point $\mathrm{E}$, which was attributed to the concentrated damage at the first storey. Consequently, it can be anticipated that soft storey mechanism might be triggered at some point beyond $140 \mathrm{~mm}$ top floor displacement.

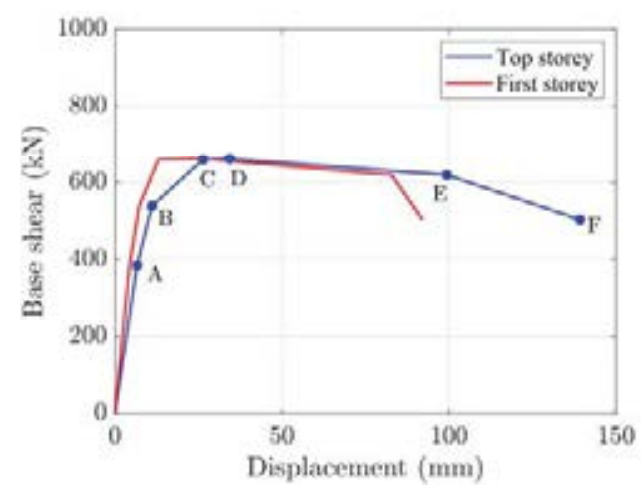

Figure 6: Comparison of backbone curves for the first and top storey of the steel frame (symmetric in the positive and negative directions). See Table 1 for more details.

\begin{tabular}{ccccccc}
\hline & $\mathrm{A}$ & $\mathrm{B}$ & $\mathrm{C}$ & $\mathrm{D}$ & $\mathrm{E}$ & $\mathrm{F}$ \\
\hline Top storey, $\mathrm{d}_{2}$ & 6.61 & 11.09 & 26.39 & 35.31 & 99.37 & 139.25 \\
First storey, $\mathrm{d}_{1}$ & 4.36 & 7.27 & 13.01 & 25.60 & 82.78 & 92.06 \\
$\mathrm{~d}_{2} / \mathrm{d}_{1}$ & 1.52 & 1.53 & 2.03 & 1.34 & 1.20 & 1.51 \\
\hline
\end{tabular}

Table 1: Distribution of displacement demands along with the height of the steel frame.

\section{NUMERICAL STUDY}

\subsection{Finite element modelling of masonry infill and steel frame}

Finite element models of the bare and infilled steel frame were built in Abaqus [22]. Only half of the 3D steel frame was modelled due to symmetry conditions and to reduce the computational cost. Meanwhile, all the internal secondary beams were excluded from the model as their contribution to the lateral resistance of the steel frame were considered negligible. All steel and masonry components were modelled using the solid element C3D8R. Figure 7 shows an overview of the Abaqus model.

The material properties were defined based on the results of material tests when possible. For parameters that could not be obtained from the tests conducted, typical values recommended in literature were adopted. The yield and ultimate strength of steel were defined to be 433 and $575 \mathrm{MPa}$, respectively, while the Young's modulus was assumed to be 210,000 MPa. On the other hand, as the masonry infill walls were modelled using macro-modelling approaches, the Young's modulus of masonry was manually adjusted to be about 3,000 MPa based on model calibration.

The concrete damaged plasticity model was used to simulate the inelastic behaviour of masonry. This model is characterised by five parameters: 1$)$ dilation angle $(\psi) ; 2)$ the flow potential eccentricity $(\varepsilon) ; 3)$ the ratio between initial equibiaxial compressive yield stress to initial 
uniaxial compressive yield stress $\left(\mathrm{f}_{\mathrm{b}} / \mathrm{f}_{\mathrm{c} 0}\right)$; 4) the ratio between second stress invariant on the tensile meridian to that on the compressive meridian at initial yield $(\mathrm{K})$, and 5) the viscosity parameter $(\mu)$. Values recommended by D'Altri et al. [19], reported in Table 2 were adopted in this study as typical assumptions for masonry infill. Besides, the compressive and tensile strength of masonry were defined to be 5.70 and $1.30 \mathrm{MPa}$, respectively. Furthermore, the composite slabs were modelled as rigid bodies to simulate the rigid diaphragm behaviour and ensure a smooth transfer of load to the steel frame. Lastly, a $75 \mathrm{~mm}$-thick concrete block was included in the model as the base of ground floor masonry infill. Since no damage was observed on this concrete base during the experimental test, it was assumed to behave in the elastic range with a Young's modulus of 35,000 MPa.

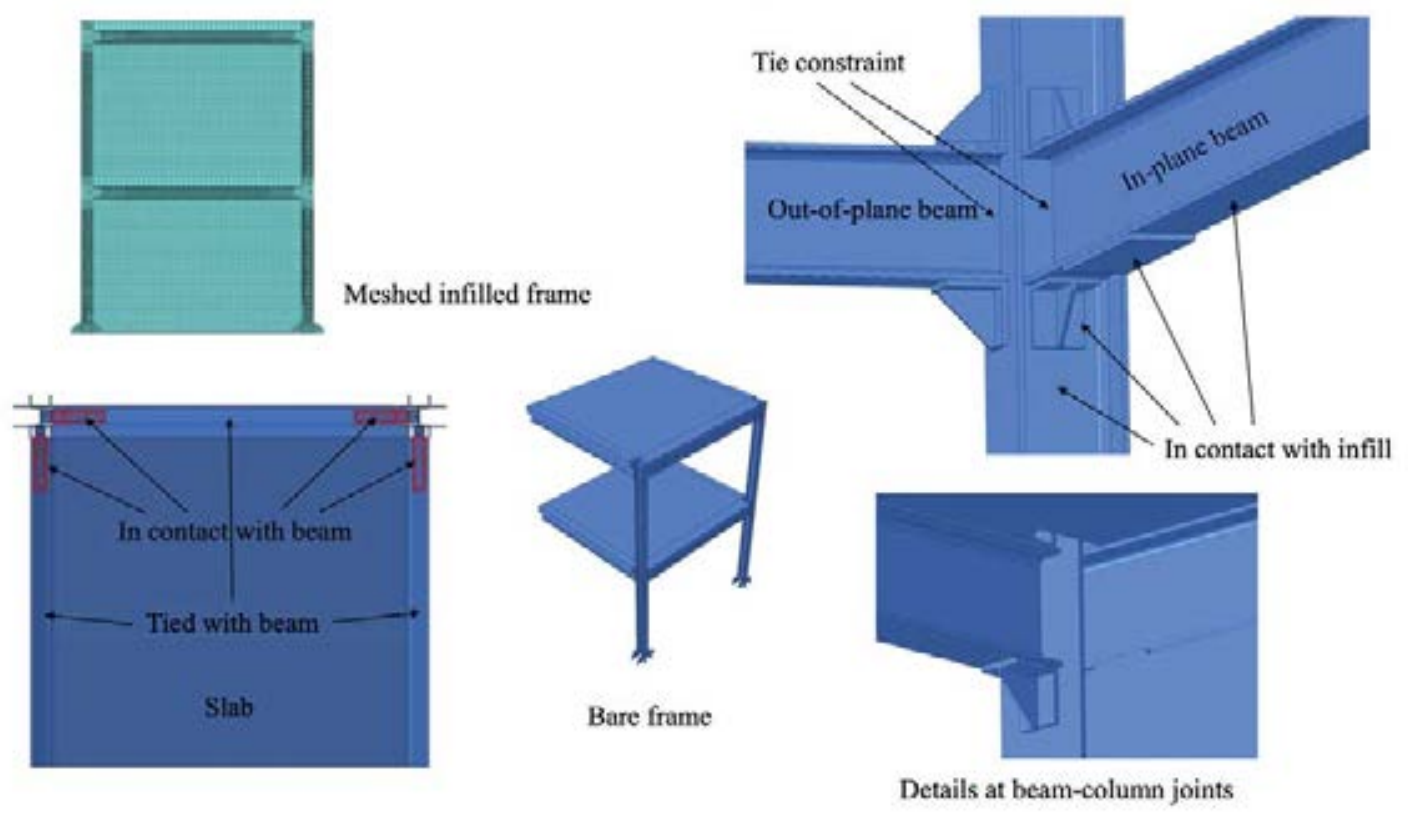

Figure 7: Numerical models of the steel frame in Abaqus using macro-model of masonry infill.

\begin{tabular}{ccccc}
\hline$\psi$ & $\varepsilon$ & $\mathrm{fb}_{\mathrm{b}} / \mathrm{f}_{\mathrm{c} 0}$ & $\mathrm{~K}$ & $\mu$ \\
\hline $10^{\circ}$ & 0.1 & 1.16 & 0.667 & 0.0005 \\
\hline
\end{tabular}

Table 2: Parameter to define the inelastic behaviour of masonry infill using concrete damaged plasticity model in Abaqus [21].

Beam-to-column joints, stiffeners, and cover plates of the beam-to-beam connections were modelled through tie constraint. Appropriate boundary conditions were applied at the end of the transverse beams to simulate the structure's symmetric condition. Besides, in the region with shear connectors, a tie constraint was used to simulate the slab-beam interaction. Conversely, for the region without shear studs, a surface-to-surface contact interaction was defined between the slab and the beam with 'Hard' normal behaviour and a friction coefficient of 0.7 for the tangential behaviour. Lastly, a surface-to-surface contact (with the same properties as above) was also introduced to simulate the masonry infill and steel frame interaction. 


\subsection{Model validation}

The numerical models' validation was performed with respect to the stiffness and dynamic properties observed during the snap-back tests. During this test, lateral loads of 13 and $31 \mathrm{kN}$ were imposed on the top storey of the bare and infilled frame, respectively. The comparisons of the numerical and experimental lateral displacement profiles are shown in Figure 8 and reported in Table 3.

As shown in Figure 8, both the bare and infilled frame models achieved a 'good' match of lateral displacements with the test mockup, and the discrepancies were all within $10 \%$. In both cases, the comparison of the numerical and experimental results show a nearly identical initial lateral stiffness at the first storey. Conversely, the top storey's lateral stiffness was slightly underestimated in the bare frame and slightly overestimated when the masonry infills were present.
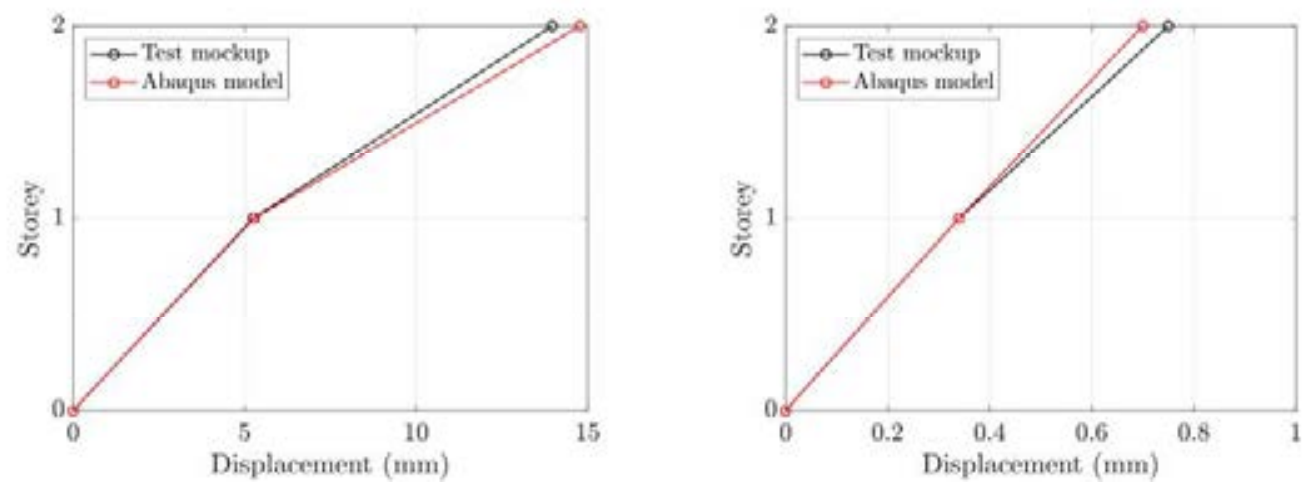

Figure 8: Comparisons of lateral displacement profile of the bare frame (left) and the infilled frame (right) during the modal characterisation test.

\begin{tabular}{c|cc|cccc}
\hline \multirow{2}{*}{} & \multicolumn{3}{|c|}{ Test } & \multicolumn{4}{c}{ Abaqus } \\
\cline { 2 - 7 } & First floor & Top floor & \multicolumn{2}{c}{ First floor } & \multicolumn{2}{c}{ Top floor } \\
\hline Bare & 5.25 & 13.97 & 5.28 & $+0.57 \%$ & 14.78 & $+5.80 \%$ \\
Infilled & 0.34 & 0.75 & 0.34 & $0.00 \%$ & 0.70 & $-6.67 \%$ \\
\hline
\end{tabular}

Table 3: Comparisons of the lateral displacements of the steel frame obtained numerically and experimentally.

\subsection{Pushover analysis}

The results of the pushover analysis is presented hereafter. The numerical model was pushed up to $140 \mathrm{~mm}$ at the top storey, which was the maximum lateral displacement measured during the test. The pushover analysis was done assuming three displacement ratios of top storey to first storey $\left(\mathrm{d}_{2} / \mathrm{d}_{1}\right)$. When the top storey displacement was less than $30 \mathrm{~mm}$, the ratio $d_{2} / d_{1}$ was assumed to be 1.5 . Then when the top storey displacement was between 30 and $100 \mathrm{~mm}$, the ratio $\mathrm{d}_{2} / \mathrm{d}_{1}$ reduced linearly from 1.5 to 1.2 . Eventually, when the top storey displacement was larger than 100 , the ratio $\mathrm{d}_{2} / \mathrm{d}_{1}$ was equal to 1.2 . Figure 9 presents the comparison between the pushover curve, i.e., the top storey displacement-base shear relation, and the structural response of the steel frame measured during the experimental test, while Figure 10 shows the evolution of stress distribution in the infill walls during the pushover analysis.

It can be seen that in general the numerical model were in good agreement with the test results when the displacement was smaller than $30 \mathrm{~mm}$. However, the numerical model failed to capture the deterioration of strength which took place beyond $30 \mathrm{~mm}$ top storey displacement. 
This is because that firstly a bi-linear relation was assumed for the mechanical property of masonry, which did not account for the strength degradation. Besides, the simplified modelling approach adopted was unable to simulate the falling of crushed bricks at the top corners. Consequently, the base shear of the numerical model continued to increase beyond the actual point of the onset of strength and stiffness degradation.

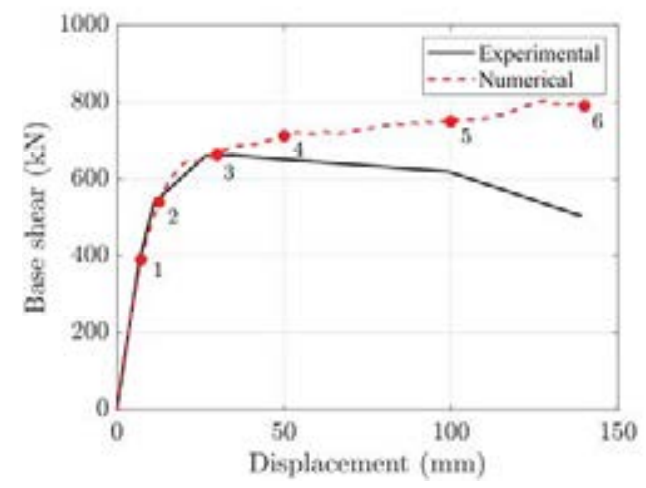

Figure 9: Pushover curve of infilled steel frame.

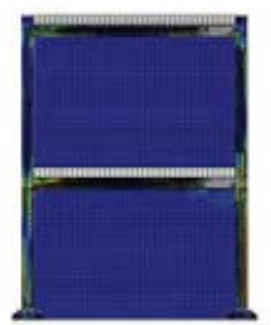

(a)

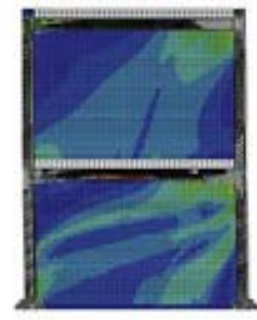

(d)

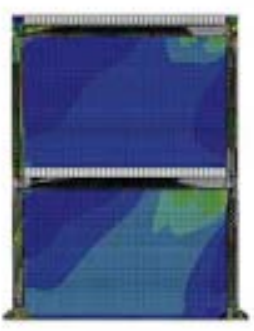

(b)

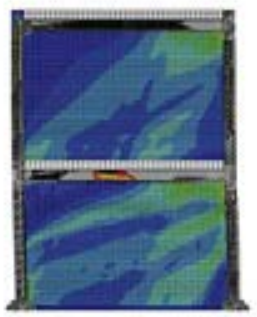

(e)

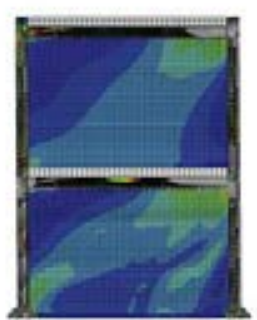

(c)

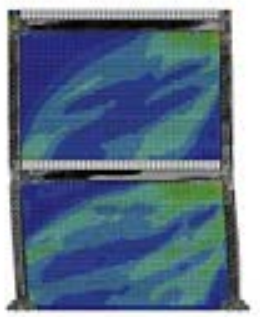

(f)

Figure 10: Stress contour of the masonry infill walls during the pushover analysis (See Figure 9): a) Point 1; b) Point 2; c) Point 3; d) Point 4; e) Point 5; f) Point 6.

As can be seen in Figure 10(a), initially when the model was within the elastic range, stress concentration was noticed at both storeys surrounding the beam splice connections before any struts were formed in the infill walls. This illustrated the occurrence of cracks at the top corners of each infill wall, which were due to the interlock between the bolts of beam splice connections and the top layer of bricks. When the displacement demand was increased, an inclined strut was formed within the lower storey infill wall, as can be seen in Figure 10(b). Successively, when the top floor displacement was approaching $30 \mathrm{~mm}$ (Point 3 in Figure 9), the previous strut was split into a diagonal strut and an off-diagonal strut, as shown in Figure 10(c), and the diagonal strut appeared to be wider than the off-diagonal strut. In the meantime, an inclined strut started to form in the top floor infill wall as well, which had a similar shape 
to the one previously formed in the lower storey infill wall. When the displacements at both storeys of the infilled steel frame were further increased, as shown in Figure 10(d) to (f), the contact length between the infill and the surrounding steel members remained almost unchanged, and the diagonal strut in the lower storey infill wall was further split into two smaller struts. It is clear that the upper strut connected the top corner and the end of contact length over the other column, while the middle strut connected the bottom corner and the mid-point of the contact length over the other column. Figure 10(f) also shows the tendency that with increasing lateral displacement, the upper strut would become wider, and the middle and lower struts might eventually become one single strut that has approximately the same width as the upper strut. It was also noticed that despite the infill wall on the top floor exhibited the same behaviour as that on the lower floor, the two infill walls contained different numbers and geometried of struts at the same step of pushover, which indicated that it might not be appropriate to use the same simplified strut model to represent the infill walls on different floors.

\section{CONCLUSIONS}

This paper presented numerical modelling of infilled steel frame using a macro-model of masonry infill. It was concluded that the steel joints that were in contact with masonry infill caused local stress concentration in the part of infill wall adjacent to the joints. Besides, a single inclined strut was noticed at small displacement, when the overall structural was within the elastic range. Subsequently, when the displacements at both storeys became larger, the single strut was firstly split into two struts and eventually became three struts. The width of struts was also found to be changing during the pushover analysis. Moreover, the contact length over beams and columns were also observed, which initially increased with increasing displacement and then remained approximately constant. Lastly, it was also concluded that the masonry infill on different floors could form different numbers of struts with varying geometries, which should be taken into consideration when developing simplified strut models.

Future studies should be conducted using a more detailed micro-model of masonry infill to investigate the development of cracks in the infill walls and achieve more accurate observation of infill-frame interactions.

\section{REFERENCES}

[1] British Standards Institution, BS EN 1998-3:2005, Eurocode 8. Design of structures for earthquake resistance - Part 3: Assessment and retrofitting of buildings. London, 2005.

[2] J.L. Dawe, C.K. Seah, Behaviour of masonry infilled steel frames. Canadian Journal of Civil Engineering, 16(6), 865-876, 1989.

[3] M.N. Fardis, T.B. Panagiotakos, Seismic design and response of bare and masonryinfilled reinforced concrete buildings part II: infilled structures. Journal of Earthquake Engineering, 1(03), 475-503, 1997.

[4] M. Dolšek, P. Fajfar, The effect of masonry infills on the seismic response of a fourstorey reinforced concrete frame - a deterministic assessment. Engineering Structures, 30(7), 1991-2001, 2008.

[5] L. Liberatore, L.D. Decanini, Effect of infills on the seismic response of high-rise RC buildings designed as bare according to Eurocode 8. Ingegneria Sismica, 3, 7-23, 2011. 
[6] D. Markulak, I. Radić, V. Sigmund, Cyclic testing of single bay steel frames with various types of masonry infill. Engineering Structures, 51, 267-277, 2013.

[7] L. Di Sarno, J.-R. Wu, M. D’Aniello, S. Costanzo, R. Landolfo, O-S. Kwon, F. Freddi, Assessment of existing steel frames with infills under multiple earthquakes. M. Papadrakakis, M. Fragiadakis eds. $7^{\text {th }}$ ECCOMAS Thematic Conference on Computational Methods in Structural Dynamics and Earthquake Engineering (COMPDYN 2019), Crete, Greece, June 24-26, 2019.

[8] L. Di Sarno, J.-R. Wu, Seismic assessment of existing steel frames with masonry infills. Journal of Constructional Steel Research, 169, 106040, 2020.

[9] M. Dolšek, P. Fajfar, Soft storey effects in uniformly infilled reinforced concrete frames. Journal of Earthquake Engineering, 5(01), 1-2, 2001.

[10] G.M. Verderame, F. De Luca, P. Ricci, G. Manfredi, Preliminary analysis of a softstorey mechanism after the 2009 L' Aquila earthquake. Earthquake Engineering and Structural Dynamics, 40(8), 925-944, 2011.

[11] H. Zuo, W. Zhang, B. Wang, X. Gu, Seismic behaviour of masonry infilled hinged steel frames with openings: experimental and numerical studies. Bulletin of Earthquake Engineering, 19(3), 1311-1335, 2021.

[12] M.M. Ghazimahalleh, Stiffness and damping of infilled steel frames. Proceedings of the Institution of Civil Engineers-Structures and Buildings, 160(2), 105-118, 2007.

[13] K.F. Najarkolaie, M. Mohammadi, N. Fanaie, Realistic behavior of infilled steel frames in seismic events: experimental and analytical study. Bulletin of Earthquake Engineering, 15(12), 5365-5392, 2017.

[14] W.W. El-Dakhakhni, M. Elgaaly, A.A. Hamid, Three-strut model for concrete masonryinfilled steel frames. Journal of Structural Engineering, 129(2), 177-185, 2003.

[15] M. Yekrangnia, M. Mohammadi, A new strut model for solid masonry infills in steel frames. Engineering Structures, 135, 222-235, 2017.

[16] L.F. Gutiérrez-Urzúa, F. Freddi, L. Di Sarno, Comparative Analysis of Code Based Approaches for the Seismic Assessment of Existing Steel Moment Resisting Frames. Journal of Constructional Steel Research, 181, 106589, 2021.

[17] P.B. Lourenço, J.G. Rots, Multisurface interface model for analysis of masonry structures. Journal of engineering mechanics, 123(7), 660-668, 1997.

[18] K.F. Abdulla, L.S. Cunningham, M. Gillie, Simulating masonry wall behaviour using a simplified micro-model approach. Engineering Structures, 151, 349-365, 2017.

[19] A.M. D’Altri, S. de Miranda, G. Castellazzi, V. Sarhosis, A 3D detailed micro-model for the in-plane and out-of-plane numerical analysis of masonry panels. Computers and Structures, 206, 18-30, 2018.

[20] P.B. Lourenço, J.G. Rots, J. Blaauwendraad, Continuum model for masonry: parameter estimation and validation. Journal of Structural Engineering, 124(6), 642-652, 1998.

[21] J. Yacila, G. Camata, J. Salsavilca, N. Tarque, Pushover analysis of confined masonry walls using a 3D macro-modelling approach. Engineering Structures, 201, 109731, 2019. 
[22] Dassault Systèmes, ABAQUS/Standard User's Guide, Version 6.14. Dassault Systèmes Simulia Corp., Providence, RI, USA. 